\title{
PRESCRIPTION ADRIFT IN A SEA OF SERVITUDES: POSTMODERNISM AND THE LOST GRANT
}

\author{
MARK A. ClaWSON \\ INTRODUCTION
}

When pressed to defend his subversive statements about Denmark, Shakespeare's Hamlet falls back on eminently defensible territory. He opts for the primacy of personal opinion by acknowledging that "there is nothing either good or bad, but thinking nrakes it so. To me it is a prison." The mherent subjectivity of this statement appears, at first glance, to bear hittle comparison to legal reasoning. Hamlet's words seem to imvite conclusions based on free-wheehing opinion, whereas modern legal minds feel most comfortable resting their conclusions on more objective rules of law. This dichotomy of subjective and objective reasoning, however, is the starting point of postmodern analysis. ${ }^{2}$ Postmodern methods of imterpretation, despite their detractors, ${ }^{3}$ transcend the

1. William Shakespeare, The Tragedy of Hamlet act 2, sc. 2.

2. See Martin F. Katz, After the Deconstruction: Law in the Age of PostStructuralism, 24 U.W. ONTARIO L. REV., June 1986, at 51.

3. Detractors of postmodern approaches to legal interpretation often attack these analytical tools as nothing more than mere nihilism, but their discomfort with postmodern thought is most often based on a profound distaste for what they consider to be radical ideology. See, e.g., Paul D. Carrington, Of Law and the River, 34 J. Legal EduC. 222, 227 (1984). (suggesting that universities employing nihilist professors are "inore likely to train crooks than radicals"); Stephen L. Carter, Constitutional Adjudication and the Indeterminate Text: A Preliminary Defense of an Imperfect Muddle, 94 YALE L.J. 821, 822-23 (1985) (lamenting the "delegitimizing assault" on conventional constitutional theory and suggesting methods of repulsing the assault); Owen M. Fiss, The Death of Law?, 72 CoRNELL L. REV. 1, 1 (1986) (arguing that Critical Legal Studies scholars "endanger the proudest and noblest ambitions of the law"); John Stick, Can Nihilism Be Pragmatic?, 100 HARv. L. REv. 332, 335-38 (1986) (suggesting that "nihilist" approaches such as Critical Legal Studies "misuse much of the philosophy they attempt to appropriate" and concluding that they fail to fully discuss politics and should therefore take a more direct approach to legal doctrines and reasoning). 
political agendas of individual pressure groups and facilitate a more thorough comprehension of linguistic, and therefore legal, structures. ${ }^{4}$

Postmodernism may originate in the tension between subjective and objective interpretations, but its application reveals the complexity hiding beneath this simple dichotomy. It fosters new interpretations and makes possible an escape from troublesome fornulations previously accepted without question. To make any use of postmodernism, we should see deconstruction as an analytical tool capable of leading to new msights but incapable of offering conclusions. Furthermore, the conclusion of any deconstructive exercise is itself subject to attack by the same deconstructive process. A pragmatic, interpretive approach is similarly incapable, in and of itself, of rendering stable conclusions. It is an imterpretive posture that allows the process of legal reasouing to gain a certain level of transparency. The approaches presented in this Note-Jacques Derrida's deconstruction ${ }^{5}$ and Stanley Fish's pragmatism ${ }^{6}$ - represent means, not ends. As analytical tools and interpretive postures, postinodern theories can help one understand the processes that lie beneath the surface of legal theory and practice.

This Note apphes postmodern legal theory to the law of property. Although these analytical tools and interpretive postures could be applied to any area of the law, the confusing language and convoluted history of property law, and specifically prescription, provide a perfect context for the application of postmodern analysis. Because the law of property relies on language as much as any otlier area of law, ${ }^{7}$ different characterizations of ownership or use, highly abstract concepts themselves, result in the creation of vastly varied property rights and affect one's ability to utilize effective remedies. The imphications of language deterinine whether interests vest, leases cease, or owners sue.

4. For a background discussion of postmodern theory, see Peter C. Schanck, The Only Game in Town: An Introduction to Interpretive Theory, Statutory Construction, and Legislative Histories, $38 \mathrm{KAN}$. L. REV. 815 (1990) (presenting contemporary legal interpretive theory in four broad categories); see also Christopher Norris, Law, Deconstruction, and the Resistance to Theory, 15 J.L. \& Soc'Y 166, 166 (1988) (noting that interpretive arguments generally fall into certain categories and "[f]or every position adopted by the partisans of this or that literary theory one can find a corresponding argument developed in the context of legal interpretation").

5. See infra Section $\mathrm{I}(\mathrm{B})$.

6. See infra Section I(C).

7. See infra Part II. 
Within the common law, servitudes developed with particular reliance on linguistic differentiation. ${ }^{8}$ Historically, servitudes arose as private land use arrangements, but courts eventually developed a system of easements, equitable servitudes, and real covenants to escape precedential barriers. ${ }^{9}$ These abstract legal structures allowed parties to significantly alter their rights and burdens solely on the basis of how they chose to characterize their arrangements.

By allowing contimued trespass to develop into a legal property right, the doctrine of prescription ${ }^{10}$ has carved out a particularly interestimg miche within this linguistic framework. ${ }^{11}$ Because the trespass of prescriptive user ${ }^{12}$ results in the transfer of property rights to malfeasors, common law rationales have reluctantly given an aura of legal legitimacy to bestowal of rights justified only by pragmatism. The fictional "lost grant" developed as an evidentiary presumption that, because of long use, an original owner must have granted the property rights in question to the current possessor. ${ }^{13}$ The grant was entirely fictional, however, and the trou-

8. Seen in historical context, it is not difficult to determine why some commentators reserve special aninosity for the common law system. "[T]his is not an area of land law in which the common law performance deserves admiration. Rather it is one where rigid categories, silly distinctions, and unreconciled conflicts over basic values have often led to unhappy results for landowners." ChARLes M. HAAR \& LANCE LIEBMAN, PROPERTY AND LAW 703 (1977).

9. See infra Section II(A).

10. Prescription is the legal doctrine that allows long-continued use (or, in property parlance, user, see infra note 12) to develop into an imcorporeal (or intangible) property right such as an easement. Adverse possession, on the other hand, is a legal doctrine that allows possession to become a corporeal (or tangible) property right, i.e. legal ownership of the property. Thus, if property ownership is conceptualized as a bundle of sticks, prescription leads to the acquisition of a few sticks, whereas adverse possession yields the whole bundle. See Roger A. Cunningham ET AL., THE LAW OF Property 450-56 (1984).

11. See infra Section II(B). William Holdsworth, along with nuany other comnentators, showed open distaste for the law of prescription. He wrote that "there is no branch of English law which is in a nore unsatisfactory state .... [N]o mere restatement can clear up the muddle which the courts and the Legislature have combined to make of the law of prescription." 7 WILLIAM S. HOLDSWORTH, HISTORY OF THE ENGLISH LAW 352 (1926); see also EMORY WASHBURN, 2 A TREATISE ON THE AMERICAN LAW OF REAL PROPERTY 33 (5th ed. 1887) (noting that the law of prescription presents a "numerous and difficult class of cases").

12. "User" is a term of art that implies use satisfying the legal requirenents of prescription. See CUNNINGHAM ET AL., supra note 10, at 451.

13. See William E. Burby, HandBooK of THE LAW OF REAL PRoperty 77 (1965); CUNNINGHAM ET AL., supra note 10, at 451. 
blesome proposition of allowing property rights to pass to productive users mevitably resulted in the rewarding of tortious conduct.

The tension between property ownership and transfer to productive users underhes prescription and perhaps explains why the fictional lost grant has fallen into disfavor. ${ }^{14}$ Because of this disfavor, courts grapple with other justifications for the law of prescription, such as analogy to adverse possession. ${ }^{15}$ Modern minds view fictions as excess theoretical baggage that detract from the smoothness of a mechamical approach, but modern views fail to appreciate the mcongruence of their own mechanical language. A postmodern analysis of the lost grant doctrine and prescription reveals that a fiction by any other name is still a fiction. Furthermore, postmodern analysis of the lost grant doctrine and the mechanical tests advocated in its place reveals that the lost grant doctrine, despite modern attempts to circumvent it, served as an adequate, if not a more straightforward, arbiter of coinpeting interests. As a metaphor, the fictional lost grant implies that the transfer of property rights through prescription is also fictitious. Postmoderinisn reveals that the inechanical rules of adverse possession avoid metaphors and symbols yet accomplish the saine "fictional" transfer of property rights.

Part I of this Note presents and analyzes postınodern concepts of deconstruction and interpretive theory. Part II summarizes the lengthy history of servitudes and prescription before proceeding to an analysis of the confusion that surrounds the lost grant doctrine. Part III uses the interpretive tools of postmoderinisin to analyze why nodern courts and commentators have reinoved the fictional lost grant froin its place as the theoretical basis for the legal doctrine of prescription and replaced it with mechanical approaches borrowed fron adverse possession. Deconstructing the arguments against "prescription by analogy to lost grant," this Note shows that they apply equally well to "prescription by analogy to adverse possession"-neither rationale stands on a firm conceptual founda-

14. See infra Section MI(B); see also BURBY, supra note 13, at 77 ("The fiction of a 'lost grant' has, in general, been discarded."); CUNNINGHAM ET AL., supra note 10, at 451 ("Lost grant is part of the historical development of American prescription law, but that is all. . . Except for historical purposes, discussions of the subject should drop out of the legal literature.").

15. See, e.g., Warlick v. Rome Loan \& Fin. Co., 22 S.E.2d 61 (Ga. 1942); Plaza v. Flak, 81 A.2d 137 (N.J. 1951); DiLeo v. Pecksto Holding Corp., 109 N.E.2d 600 (N.Y. 1952). 
tion. This insight reveals that the disdain for the lost grant doctrine may conceal intellectual insecurity about our conception of property ownership. In "reality," there was no grant, but postmodern analysis reveals another, equally valid, "reality"- the modern conception of property ownership is a fictional construct just like the lost grant.

\section{POSTMODERNISM}

Any discussion of meaning or understanding in the legal context begins witl the assumption that legal endeavor hinges on issues of interpretation. ${ }^{16}$ Just as in hiterary circles, "jurists [have] become factioned over a debate represented by the dichotomy of objective and subjective." ${ }^{17}$ This interpretive debate tends to "polarise between those who believe in the authority of origins, imtentions, or historical warrant, and those who argue for a more liberal approach to questions of legal precedent, regarding law as a text open to remterpretation in tlie light of changing social and pohtical realities." 18

While this debate rages, witlı individual commentators taking refuge behind party lines, students and practitioners of the law may wonder about the importance, even the relevance, of understanding postmodern theory. Simply stated, postunodernisin opens up new avenues of thouglit and facilitates new interpretive possibilities by allowing subjective interpretations equal footmg alongside well-entrenched objectivist viewpoints. That which appears cryptic can unexpectedly become transparent when viewed througlı a postmodern lens.

16. Schanck, supra note 4 , at $815 \&$ n.2 ("[W]hoever hath an absolute Authority to interpret any written, or spoken Laws; it is $\mathrm{He}$, who is truly the Law-giver, to all Intents and Purposes; and not the Person who first wrote, or spoke them.") (qnoting BENJAMIN B. HoAdLy, THE NATURE OF THE KINGDOM, OR CHURCH, OF ChRIST 12 (1717), reprinted in JOHN CHIPMAN GRAY, THE NATURE AND SOURCES OF THE LAW 102 (2d ed. 1921)).

17. Katz, supra note 2, at 51 ("Broadly and superficially stated, the [objective] is concerned with restricting the scope of legitimate interpretations to the letter of the text, allowing the text to identify or define itself, while the [subjective] is considered to refer to one party's or one reader's personal or private understanding of the text.").

18. Norris, supra note 4 , at 166. 


\section{A. Postmodernism's Philosophical Background}

The term "postmodernism" itself encompasses a number of different theories and practices. Sometimes terms such as "structuralism," "poststructuralism," and "deconstruction" are bandied about as if synonymous, ${ }^{19}$ but their differences become apparent when one views them in historical contexts.

Most often, advocates of radical pohtical thought have invoked postmodern ideas to undermine "beliefs still prevalent in (especially American) culture but derived from the Enlightenment."20 The humamists of the Enlightenment placed human insights, primcipally those of authors, at the peak of any interpretive pyramid because humanist thought "presupposed a view of language as something capable of grasping reality." ${ }^{21}$ The structuralists, on the other hand, later argued that, instead of an author's language reflecting reahty, the structure of language actually produced reality; meaumg is not determined by the individual but by the system governing the individual. ${ }^{22}$ At the center of structuralisin was a "scientific ambition to discover the codes, the rules, the systems, which underlie all human social and cultural practices."23

19. See, e.g., Thomas C. Heller, Structuralism and Critique, 36 STAN. L. REV. 127, 155 (1984) ("[P]oststructuralism must incorporate structuralism's deconstruction."); Cheah Pheng, The Law of/as Rape: Poststructuralism and the Framing of the Legal Text, 9 LAW CONTEXT 117, 118-19 (1991) (discussing the "vulgarisation" in academic usage of "poststructuralism" and "deconstruction"); Michel Rosenfeld, Deconstruction and Legal Interpretation: Conflict, Indeterminacy and the Temptations of the New Legal Formalism, 11 CARDOZO L. REV. 1211, 1211-12 (1990) (referring to the "multifaceted dimensions" of the Critical Legal Studies movement through an overbroad use of "deconstruction").

20. Jane Flax, Postmodernism and Gender Relations in Feminist Theory, in FEMINIST THEORY IN PRACTICE AND PROCESS 51, 54 (Micheline R. Malson et al. eds., 1989). Flax lists holdover beliefs from the Enlightenment that postmodernism seeks to throw into doubt. The existence of a stable, coherent self that is capable of using universal reason to reach conclusions grounded in science, and therefore truth, is central to these holdover beliefs. Imphicit in these ideas is a view that, "[j]ust as the right use of reason can result in knowledge that represents the real, so, too, language is merely the medium in and through which such representation occurs." Id. at 54-55.

21. RAMAN SELDEN, A READER'S GUIDE TO CONTEMPORARY LITERARY THEORY 66 (2d ed. 1989). Selden further notes that humanist critics thought of language "as a reflection of either the writer's mind or the world as seen by the writer. In a sense the writer's language was hardly separable from his or her personality." Id.

22. Id. that

23. Id. (emphasis omitted). Discussing structuralism, Christopher Norris has written

[t]here is simply no access to knowledge except by way of language and other, related orders of representation. Reality is carved up in various ways according to the unanifold patterus of sameness and difference which various languages 
With time, however, poststructuralist thinkers "[sought] to deflate the scientific pretensions of structuralism"24 while simultaneously continuing to build on its foundation. Whereas structuralism had noted the inherent nature of language to vary between words ("signifiers") and concepts ("signifieds"), poststructuralism emphasized the unstable nature of all signification. It postulated that language was not a unitary structure with two sides ${ }^{25}$ but rather a "momentary 'fix' between two moving layers."26 Thus, poststructuralists believe that the structuralist attempt to "master the text and to open its secrets ... . is vain because there are unconscious, or linguistic, or historical forces whicls cannot be mastered. The signifier floats away from the signified .....27 This unstable nature of langnage forms the central tenet in poststructuralist tlieory.

\section{B. Deconstruction}

Ratlier than attempting to give answers, the nature of poststructuralisin is to ask questions by noting the differences between what a text actually says and what it purports to say. ${ }^{28}$ Against this backdrop, deconstruction lias developed as a "means of demonstrating thiat what appears to be the 'correct' or most defensible interpretation is not that at all, that there is always more than one plausible and justifiable interpretation"29 of any

provide. This basic relativity of thought and meaning $\ldots$ is the starting-point of structuralist theory.

Christopher NORRIS, DECONSTRUCTION 5 (rev. ed. 1990).

24. SELDEN, supra note 21, at 70 ("If structuralism was heroic in its desire to master the world of man-made signs, poststructurahism is comic and anti-heroic in its refusal to take such claims seriously.").

25. Selden observes that structuralist theorists such as Ferdinand de Saussure viewed signifier and signified as two sides of one coin; however, they also realized that

there is no necessary connection between signifier and signified. Sometimes a language will have one word (signifier) for two concepts (signifieds): in English "sheep" is the arimal and "mutton" the meat; French has only one word for both signifieds ("mouton"). It is as though the various languages carve up the world of things and ideas into different concepts (signifieds) on the one hand, and different words (signifiers) on the other.

Id. For a general discussion of Saussure's linguistic theories, see FERDINAND DE SAUSSURE, COURSE IN GENERAL LINGUISTICS (Wade Baskin trans., 1974).

26. SELDEN, supra note 21 , at 71 .

27. Id. at 109. Of course, this instability leads directly to the principal criticisu of poststructurahist theory: it cannot lead to a single definitive interpretation because every conclusion is equally subject to attack. See Schanck, supra note 4 , at 829 .

28. See SELDEN, supra note 21 , at 109-10.

29. Schanck, supra note 4 , at 821 . Schanck notes that deconstruction, a post- 
text. The practice of deconstruction finds its origin in the writings of the French philosopher Jacques Derrida. ${ }^{30}$ Derrida is interested in the congruence and incongruence between the signs one uses to convey meaning and what one actually intends to say. ${ }^{31}$ Christopher Norris, a scholar of hiterary theory, has observed that deconstruction terminology has been used in two distinct senses. On the one hand, it is used to imply a free-wheeling desire to "trash" tradition in the name of "pet ideological agenda." On the other hand it imphes, less prejudicially, a method of closely reading texts to see how they contradict themselves and "undermine more traditional, naive ways of reading. ${ }^{332}$

Deconstruction is not, in the words of one legal scholar, "simply a fancy way of sticking out your tongue, but a practice that raises important philosophical issues for legal thinkers." ${ }^{333}$ Since deconstruction should be viewed as a practice, rather than a philosophical position, J.M. Balkin, a law professor interested in the apphication of deconstruction to legal issues, has identified two issues of analytical relevance to legal practitioners: the inversion of hierarchies and the liberation of the text from the author. ${ }^{34}$

structuralist theory, is often classified as a school of postmodern philosophy. He notes further that poststructuralism, although it contains many elements of structuralism, has evolved beyond and also in opposition to some basic tenets of structuralism. Id. Poststructuralists and postmodernists "generally reject the idea of a single textual meaning, rational understanding, objective knowledge, the autonomous individual, universal morality, and any other overarching or totalizing theory." Id. at 821 n.34.

30. See, e.g., JACQUES DERRIDA, DISSEMINATION (Barbara Johnson trans., 1981); JACQUES DERRIDA, MARgINS OF PHILOSOPHY (Alan Bass trans., 1982); JACQUES DERRIDA, OF GRAMmatology (Gayatri C. Spivak trans., 1976); JACQUeS DeRrIDA, WRITING AND DIFFERENCE (Alan Bass trans., 1978). (1987).

31. J.M. Balkin, Deconstructive Practice and Legal Theory, 96 YALE L.J. 743, 744

32. NoRRIS, supra note 23 , at 137.

33. Balkin, supra note 31 , at 744 . Balkin notes three reasons why lawyers should find interest in deconstructive techniques.

First, deconstruction provides a method for critiquing existing legal doctrines; in particular, a deconstructive reading can show how arguments offered to support a particular rule undermine themselves, and instead, support an opposite rule. Second, deconstructive techniques can show how doctrinal arguments are informed by and disguise ideological thinking. ... Third, deconstructive techniques offer both a new kind of interpretive strategy and a critique of convenId. tional interpretations of legal texts.

34. Id. at 746. 
1. The Inversion of Hierarchies. The first of these tools- of deconstructive practice, the inversion of hierarchies, involves the "identification of hierarchical oppositions, followed by a temporary reversal." ${ }^{\text {"35 }}$ For example, hierarchies are established when certain ideas are accepted as more valid than others. These ideas are then said to be in opposition, and a deconstructive reversal changes the hierarchy. The objective of this exercise is not to establish a new, conclusive interpretation, but to examine what happens when the conventional arrangement is reversed. ${ }^{36}$ Derrida beheves that insights come when the privileging of hierarchies is reversed. If $\mathrm{A}$ is given certain quahties, such as being the general rule-simple, normal, or true-and B is given the opposing quahities of being the exception-complex, abnormal, or false-then a deconstructionist reversal will show that the qualities assigned to $A$ are true of $B$ and the qualities assigned to $B$ are true of $A .{ }^{37}$ Thius, "A's privileged status is an illusion, for $A$ depends upon $B$ as much as $B$ depends upon A, ... [and B actually] stands in relation to $A$ inuch like we thought $A$ stood in relation to $B .{ }^{38}$ The aim of this exercise is to observe $A$ and $B$ as we never have before; this additional insiglit comes througli a process of "intellectual discovery, which operates by wrenching us from our accustomed modes of thouglit."39

35. Id. Balkin uses Derrida's favorite example to describe inversion.

[I]f the history of Western civilization has been marked by a bias in favor of speech over writing we should investigate what it would be like if writing were more important than speech. We should atteinpt to see speech as a kind of writing, as ultimately parasitic upon writing, ... rather than the other way around. In so doing, we reverse the privileged position of speech over writing, Id. and temporarily substitute a new priority.

36. See, e.g., NORRIS, supra note 23 , at 31 (explaining that deconstruction "seeks to undo both a given order of priorities and the very system of conceptual opposition that makes the order possible"); Balkin, supra note 31, at 746-47 (explaining that the point of deconstruction is "not to establish a new conceptual bedrock, but rather to investigate what happens when the given, 'common sense' arrangeinent is reversed"); Schanck, supra note 4 , at 823 (suggesting that deconstructionists do not reverse hierarchies to create a new, correct interpretation).

37. See Balkin, supra note 31 , at 747.

38. Id.

39. Id. "[D]econstruction is not simply a strategic reversal of categories which otherwise remain distinct and unaffected. It seeks to undo both a given order of priorities and the very system of conceptual opposition that makes that order possible." NORRIs, supra note 23 , at 31 . 
Balkin writes of the tendency to relate the most immediate, perceptible concepts witl reality and truth through discussions of the "privileging of 'presence' in Derrida's sense of the word." When this rehance on immediacy and perception is seen as a philosophical bias, one understands why language is the central object of study for deconstructiomists. This bias, referred to as the "metaphysics of presence," ${ }^{41}$ is inherently found within language systems because language rehes on immediacy and perception. For mdividuals to communicate, their interpretations of language must correspond. This correspondence is easier if the concepts are in1mediate and easily perceptible, but this fact does not mean that immediacy and perception always correspond to truth. Thus, the study of language is, for deconstructionists, a nieans of uncovering philosophical bias. In the legal context, rules and decisions result from distinguishing the correct, and thus legal, from the incorrect and illegal. Therefore, the foundational concepts of law, inasniuch as they are considered most valid by the legal community, result fron the inherent privileging of certain concepts over others.

Several properties of language systems take on a great deal of importance in deconstructive practice. Because words, or signs, can be made in multiple contexts without destroying their meaning, communication through language is possible. ${ }^{42}$ Language systenis rely on different sigus for communication, and the difference between them distmginshes their meaning and interpretation. In deconstructionist terminology, "words carry the 'traces' of other words from which they are distinguished and in opposition to whicl they possess intelligibility." 43 When the hierarchy of more basic terins and less basic terins is deconstructed to sloow that the terins are mutually dependent, the relationship of fundaniental dependence is referred to as différance. ${ }^{44}$ These principles suggest a new way of understanding how hunıans grasp abstract ideas.

40. Balkin, supra note 31, at 748; see also NoRRIs, supra note 23, at 29 (discussing the "endless displacement of meaning" that is present in language and "everywhere disguised by the illusory 'metaphysics of presence'").

41. Balkin, supra note 31 , at 748 .

42. See SELDEN, supra note 21 , at 52-53. Iterability, a property of sigus in linguistic scholarship, implies the ability to make a sign in multiple contexts and therefore makes communication through words possible. Balkm, supra note 31 , at 748 .

43. Balkin, supra note 31, at 750; see also NORRIs, supra note 23 , at 29 (discussing the "network of relays and differential 'traces' which can never be grasped by the individual speaker").

44. Balkin, supra note 31, at 752; SELDEN, supra note 21, at 88. 
Trace and différance intimate that, rather than merely holding an immediately perceptible idea before us in our minds, we hold the idea and its opposite.

When deconstructive reversals show that the reasons given for privileging one term over another actually advocate privileging the second term, the reversal "ungrounds" the preferred conception. ${ }^{45}$ Deconstructionists use this concept to demonstrate the nature of opposing arguments to "undo theinselves."." After extensive argument and careful analysis, "[e]very signified is actually a signifier in disguise." ${ }^{\prime 47}$ Demonstrating how argunients for a preferred conception actually unground that conception reveals the power of deconstructive theory. Widely supported conclusions, and even entire intellectual traditions, have been called into doubt through the apphication of deconstructive methods. ${ }^{48}$

2. The Liberation of Text from Author. Balkin's second tool of deconstructive practice, the hiberation of text from author, relies on the inost simple paradigm of legal interpretation. According to this paradigm, correct interpretations grasp the author's intent, whereas incorrect interpretations miss the author's intent. ${ }^{49} \mathrm{Cer}-$ tain readings are therefore privileged over other readings. Deconstructionists find the hierarchy of acceptable readings subject to deconstruction and, thus, to change. ${ }^{50}$ Accordingly, new interpre-

45. Balkin, supra note 31 , at 755 ; see also Schanck, supra note 4 , at 823 ("Deconstruction is an interminable process of undermining proposed interpretations.").

46. See Balkin, supra note 31, at 755-58.

47. Id. at 760 . This is the point at which critics accuse postmodernisin of leading to nihilisin because the theories seem to deny the possibility of objective truth. Derrida's critique, however subtly, relies on a conception of truth that is unavoidably obscured by interpretation because it argues that our methods of reaching for truth are hopelessly inadequate. Id. at 760-61. Balkin asserts that, within the logocentric framework of Western thought (constructed on our notions of presence and its priunacy), signifiers can only inperfectly represent signifieds. Thus,

Derrida does not deny the existence of objective truth as much as he affirms the interpretive character of our atteinpts to coinprehend truth. Our "truth"-the conceptual apparatus we create to explain the world to ourselves-is only a sign or metaphor for an endless succession of still other signs and metaphors, and we have forgotten that it is only that. Thus, the Real Truth seems always beyond our grasp, outside the doininant conceptual apparatus, because that apparatus is necessarily always incoinplete and capable of further supplementation.

Id. at 761 .

48. SELdEN, supra note 21 , at 92.

49. Balkin, supra note 31 , at 772 .

50. See Schanck, supra note 4 , at 823 . 
tations of legal texts constantly develop. Some of these interpretations, however, are later seen as misreadings because they "are subjected to new interpretations as we read them over and over agam im different factual, historical, and pohitical contexts." ${ }^{51}$

A deconstructiomst concept called the "free play of text"-the "habit of our words to burst the seams of our intentions and to produce their own kmd of logic"s2-makes reinterpretation possible. Language inevitably contains a divergence between an author's mtention and the actual signs and metaphors of a text because "[l]egal texts, like other texts, often present later readers with new meanings, connections, and difficulties that their creators did not contemplate. These meanings are uncovered by the interpretations of successive readers in different historical and cultural contexts." ${ }^{53}$ Professor Balkin has observed that, although the rule of law appears to depend on determinate meaning and privileged interpretations, after deconstructive analysis, "[i]t is the text as read, and not the text as written, that becomes the law."54 Indeed, deconstruction reveals the tension between attempts to seek origins and the indeterminacy one finds within the free play of text. ${ }^{55}$

Deconstruction, which "by its very nature is an analytic tool and not a synthetic one," ${ }^{, 56}$ reveals the inconsistencies of privi-

51. Balkin, supra note 31 , at 775 .

52. Id. at 780. In discussing the free play of text, Balkin writes,

The structural precondition of the sign is its ability to break free from the author, and to mean other than what the author meant. The very act of "meaming" something creates a chasm between the sign and the producer's intention. This detachability makes iterability, and thus imtersubjective meaning, possible. The repetition of the sign in the new context is simultaneously a reJation of identity and difference; the repeated sign is syntactically identical, yet semantically different. The result is that the text, as it is repeatedly understood, takes on a life of its own in a relation of differance with the person who "meant" it.

Id. at 780; see also SELDEN, supra note 21, at 52-53, 90 (discussing the linguistic theory of signs, signifiers, and signifieds, as well as the ability of language to break free from context).

53. Balkin, supra note 31 , at 778 .

54. Id. at 782 .

55. See Rosenfeld, supra note 19 , at 1212 . Balkin points out that the purpose of deconstructive practice is "not to "establish that any interpretation of a text is acceptable, but that the yearning for originary meaning in the simple theory of interpretation is incomplete and cannot serve as a foundation for interpretation." Balkin, supra note 31, at 785.

56. Balkin, supra note 31 , at 786 ; see also NoRRIS, supra note 23 , at 31 ("Deconstruction is therefore an activity of reading which remains closely tied to the texts it interrogates, and which can never set up independently as a self-enclosed system 
leged and excluded concepts. Deconstructive practice itself, however, cannot posit conclusions nor replace the hierarchies that it exposes. To lead toward conclusions, the results of deconstructive practice require interpretation. Acceptance of an interpretation requires that an interpretive community be persuaded.

\section{Interpretive Communities}

Other postniodern thinkers, such as Stanley Fish, also apply their interpretive theories to both literature and law. ${ }^{57}$ One such theory is the conception that interpretation is both highly individuated and constrained by the interpreter's 'community. ${ }^{58}$ Fish's writings have been referred to as "reader-oriented theory" the context of literary criticisin and "conventionalisin" inatisn" 61 in the context of law. ${ }^{62}$ Fish's ideas build on his much-cited statement that "all activity is irrenediably interpretive." ${ }^{63}$ According to Fish, the context within which one reads a text, that is, the structure of behiefs innate to those who read it, determines the text's meaning. ${ }^{64}$ Objectivity in interpretation is

of operative concepts.").

57. See, e.g., Stanley Fish, Doing What COMES Naturally (1989).

58. But see infra note 66 and accompanying text.

59. See SELDEN, supra note 21 , at 124-26.

60. See Schanck, supra note 4 , at 833-43. Schanck notes that "the term 'conventionalism' is not a completely satisfactory designation, but it seems more closely descriptive of the theory than overly broad alternatives such as poststructuralism, postmodernism, antifoundationalism, and antiessentiahism or inaccurate alternatives, such as philosophical ideahism and pragmatism." Id. at 883 n.85.

61. See Norris, supra note 4, at 168-69.

62. Fish, like other postmodern theorists, has been amply criticized. See, e.g., Drucilla Coruell, "Convention" and Critique, 7 CARDOzo L. REv. 679 (1986); Ronald Dworkm, My Reply to Stanley Fish (and Walter Benn Michaels): Please Don't Talk About Objectivity Any More, in THE POLITICs OF INTERPRETATION 287 (W.J.T. Mitchell ed., 1983); Owen M. Fiss, Conventionalism, 58 S. CAL. L. REv. 177 (1985); David Luban, Fish V. Fish or, Some Realism About Idealism, 7 CARDozo L. REv. 693 (1986); Michael S. Moore, The Interpretive Turn in Modern Theory: A Turn for the Worse?, 41 STAN. L. REv. 871, 905-17 (1989); Pierre Schlag, Fish v. Zapp: The Case of the Relatively Autonomous Self, 76 GEO. L.J. 37 (1987).

63. FisH, supra note 57 , at 436.

64. Professor Fish has written that

interpretations rest on other interpretations, or, more precisely, on assumptions-about what is possible, necessary, telling, essential, and so on - so deeply held that they are not thought of as assumptions at all; ... the activities they make possible and the facts they entail seein not to be matters of opinion or debate, but a part of the world. 
impossible, according to Fish, because the interpretive commumty-the structure of behefs espoused by the text's interpreters-determines textual interpretation and even textual content. ${ }^{65}$

However, Fish's behef in interpretive constraint balances against this subjectivity. He sees constraint on interpretation as characteristic of the interpretive community, rather than of the text itself. ${ }^{66}$ Consequently, an infimite number of interpretations of a given text are possible, but the conventions of an interpretive community will constrain those imterpretations that are ultimately seen as valid and acceptable.

Several propositions result from this analytical framework. First, because imterpretive constraint is a function of the structure of assumptions the interpretive commumity holds, it follows that a change $\mathrm{m}$ these assumptions will change the nature of the interpretive constraimt. Second, because acts of persuasion can change the structure of behefs, acts of persuasion can result in a change in imterpretation. ${ }^{67}$ Over time, a new interpretation becomes transformed from a possible imterpretation into an accepted fact. ${ }^{68}$

Within an interpretive community, smaller subcommunities may disagree about particular interpretations, but their debate takes place within the confines of an "undisputed context."

Stanley Fish, Short People Got No Reason to Live: Reading Irony, DAEDELUS, Winter 1983, at 175, 190.

65. See Katz, supra note 2, at 54 ("[T] the reader's mind rather than the printed page.") (quoting STANLEY FISH, Is THERE A TEXT IN THIS CLASS? 37 (1980)).

66. In explaining his conception of interpretive constraint, Fish argues that it is neither the case that interpretation is constrained by what is obviously and unprobleinatically "there," nor the case that interpreters, in the absence of such constraints, are free to read into a text whatever they like. ... Interpreters are constrained by their tacit awareness of what is possible and not possible to do, what is and is not a reasonable thing to say, and what will and will not be heard as evidence in a given enterprise; and it is within those same constraints that they see and bring others to see the shape of the documents to whose interpretation they are committed.

Stanley Fish, Working on the Chain Gang: Interpretation in the Law and in Literary Criticism, 9 CRITICAL INQUIRY 201, 211 (1982).

67. Katz, supra note 2, at 54.

68. Fish writes,

[U]nassailable facts are unassailable only because an act of persuasion has been so successful that it is no longer regarded as one, and instead has the status of a simple assertion about the world. In short, there are no facts that are not the products of persuasion, and therefore no facts that stand to the side of its operations.

Fish, supra note 64, at 189 .

69. Katz, supra note 2, at 56 (citing Walter Beun Michaels, Against Formalism: The 
Thus, one can say that "acts of persuasion are conducted with the contents of undisputed contexts on the contents of what we can call disputed contexts." ${ }^{\text {70 }}$ If the acts of persuasion succeed, the interpretive community will accept the interpretation offered by one subcommunity, and that interpretation will beconie a part of the larger community's undisputed context.

\section{A Sea of Servitudes}

Perhaps no area of the law appears to differ inore fronı the avant garde pretensions of postinodernisn than the law of servitudes, an ancient tradition that bears the lasting nuarks of its confusing genealogy. Servitudes have existed in a nuniber of contexts, ${ }^{71}$ but the most disorienting servitudes coinprise the convoluted systen of easenients, real covenants, and equitable servitudes. ${ }^{72}$ This systen has been called "the most complex and archaic body of American property law renaining in the twentieth century." ${ }^{\text {"3 }}$ In its historical developinent, servitude law displays the confusion that still niarks these mcorporeal interests.

\section{A. The Context}

Modern servitude law grew out of the nedieval system of common fields that allowed communal decisions in matters of land

Autonomous Text in Legal and Literary Interpretation, 1 POETICS TODAY 23, 31 (1979)). Undisputed contexts are the building blocks with which discourse is constructed. We use these words, about whose meaning we have no disagreement, to make arguments about disputed concepts. See id.

70. Id.

71. In the past, servitudes such as profits were quite common. Easements, real covenants, and equitable servitudes make up the principal servitudes common to contemporary American law. See CUNNINGHAM ET AL., supra note 10, at 435 .

72. The following statement ranks among the more denigrating references to servitude law:

[T]he law in this area is an unspeakable quagmire. The intrepid soul who ventures into this formidable wilderness never emerges unscarred. Some, the smarter ones, quickly turn back to take up something easier like the income taxation of trusts and estates. Others, having lost their way, plunge on and after weeks of effort emerge not far from where they began, clearly the worse for wear. On looking back they see a trail they thought they broke obscured with foulsmelling waters and noxious weeds. Few willingly take up the challenge again.

Edward H. Rabin, Fundamentals of Modern Real Property Law 480 (2d ed. 1982).

73. Susan F. French, Toward a Modern Law of Servitudes: Reweaving the Ancient Strands, 55 S. CAL. L. REv. 1261, 1261 (1982). 
use. ${ }^{74}$ The rights accorded under this system, called profits $d$ prendre, allowed commumity members to put the land to its most efficient use, mcludimg entering the land and taking commodities, such as timber, game, or minerals, which were considered part of it. $^{75}$ The evolution of common fields into fenced fields and of shared pastures into consolidated farms brought on more coinplex legal structures to maintain the increasingly complex demands for land use; easements developed as a type of incorporeal hereditament. ${ }^{76}$ Positive easeinents became a means of allowing a servient owner to grant a neighbor the right to enter and perforn positive acts on the servient land. Negative easements-judicially disfavored because negative duties seem better suited to personal contracts than property rights-were limited to the four categories of hight, air, support, and interference with an artificial stream of water."

Frustration with the inability to enforce negative obligations at law resulted in efforts to create such burdens through contractual means, which led to the development of property rights characterized as real covenants. ${ }^{78}$ The burden enforceable through a real covenant was restricted by the requirements, laid out in Spencer's Case, ${ }^{79}$ that there be intent to bind successors of the covenantor, that the covenant "touch and concern" the land, and that privity ${ }^{80}$ of estate exist for a burden to run at law. ${ }^{81}$ The functional

74. See Jesse Dukeminier \& James E. KRIER, Property 788-91 (3d ed. 1993).

75. Id. at 788-89. Dukeminier and Krier note that profits were viewed as the "common wealth." Id. at 788. Distinguishing the particular requirements of profits and easements still creates conceptual difficulties in the modern British common law. See, e.g., A.H. Hudson, Problems in Prescription and Lost Modern Grant, 1986 CONVEYANCER \& Prop. LAW., Sept.-Oct., at 356, 356-60 (analyzing a 1984 New South Wales case on prescription and "lost modern grant").

76. See DUKEMINIER \& KRIER, supra note 74, at 790. "Incorporeal hereditaments" is a collective name for intangible (incorporeal) rights that descended as real property to the primogenitary heir (hereditaments), rather than as personal property to be divided among all the heirs. Medieval society distinguished between property that would descend to the oldest son and property that would be divided among, all the children. Id. at 790 n.7.

77. See id. at 851; Uriel Reichman, Toward a Unified Concept of Servitudes, 55 S. CAL. L. REV. 1177, 1187 n.42 (1982).

78. See DUKEMINIER \& KRIER, supra note 74, at 855-59; Reichman, supra note 77, at $1212-18$.

79. 77 Eng. Rep. 72 (K.B. 1583).

80. Privity later became a more complex notion encompassing both horizontal privity (the relationship between original parties to the covenant) and vertical privity (the relationship between original parties and their assignees). See DUKEMINIER \& KRIER, supra 
equivalent of negative easements eventually arose, however, in the doctrine of equitable servitudes. ${ }^{82}$ The decision in Tulk $v$. Moxhay ${ }^{83}$ established that, regardless of a covenant's enforceability at law, successors to the covenantors are bound by equity if there is intent for the promise to run, successors to the burden have notice, and the covenant fulfills the "touch and concern" requirement. ${ }^{84}$ These rights are enforceable only through equitable remedies, unlike real covenants, which are enforceable at law. ${ }^{85}$

Linguistic differentiation is the principal difference among the very similar concepts of easements, real covenants, and equitable servitudes because how one chooses to label the obligation determines which riglits are preserved and low they are enforced. Through quirks of history, the characterization we give to an abstract notion of property may have enormous implications for the nature of the riglits or obhigations created. A variance of one word may determine the enforceability of a covenant and, therefore, the potential use and value of property. Additionally, the law is full of distinctions based on language that lave outlasted their necessity. ${ }^{86}$ Although language always underlies legal discourse, this arcliaic framework of servitude law provides a uniquely convoluted backdrop for the debate and proposed modification focused on the law of prescription. Within this linguistic context, prescription-the process of acquiring the riglit to use but not possess

note 74 , at 857-59; Reichman, supra note 77 , at 1218-25.

81. See Spencer's Case, 77 Eng. Rep. at 72.

82. See DUKEMINIER \& KRIER, supra note 74 , at 854 . "The hostility to negative [easements] was ultimately overcome ... at a substantial cost in needless complexity." JESSE DUKEMINIER \& JAMES E. KRIER, PROPERTY 874 (2d ed. 1988); see also Reichman, supra note 77 , at 1225-27 (examining the historical development through which "equitable servitudes became the equity version of negative easements").

83. 41 Eng. Rep. 1143 (Ch. 1848).

84. See id.

85. Dukeminier and Krier note that the "traditionnal difference between real covenants and equitable servitudes relates to the remedy sought. The remedy for breach of a real covenant is damages in a suit at law. The remedy for breach of an equitable servitude is an injunction or enforcement of a lien in a suit im equity." DUKEMINIER \& KRIER, supra note 74 , at 865 .

86. Proposals for servitude reform often advocate merging the distinct doctrines into a larger concept of servitudes. See, e.g., French, supra note 73, at 1261; Reichman, supra note 77, at 1179. These proposals, however, also have their detractors. See, e.g., Gregory S. Alexander, Freedom, Coercion, and the Law of Servitudes, 73 CORNELL L. REV. 883, 883-85 (1988); Stewart E. Sterk, Freedom from Freedom of Contract: The Enduring Value of Servitude Restrictions, 70 IOWA L. REv. 615, 616-17 (1985). 
property-provides a well-established means of securing legally coerced property transfer. The theoretical justification for this practice, lowever, is anything but well-established.

\section{B. The History of Prescription}

Altliough some, if not most, commentators think it "ortliodox legal doctrine" ${ }^{\prime 87}$ to consider the acquisition of prescriptive riglits by analogy to adverse possession, ${ }^{88}$ prescription by analogy to the fictional lost grant, a transfer of property rights premised on a nonexistent grant that has subsequently been "lost," survives as an exceedingly difficult doctrine to replace. ${ }^{89}$ The doctrine survives because of tlie confused history of prescription as it was developed in England and as it was adopted in America.

As early as the thirteentli century, the legal historian Henry de Bracton observed tliat, "if there lias been any user extending over considerable time, exercised in peace, without any interruption and not by violence or stealtli or by virtue of a request . . . the person enjoying the riglit cannot be ousted of it, at all events without the judgment of the court." ${ }^{90}$ This pronouncement came at a time, prior to the conception of any doctrine based on the lost grant, when the doctrine of customary usage accorded rights that liad existed "time out of mind" to any individual who exercised the right. Prescription was a derivative doctrine that allowed individuals the same right to make a property interest in land use that liad been exercised from time immemorial legally enforceable. ${ }^{91}$

87. Curtis J. Berger, LAND OWNershiP AND USE 524 (3d ed. 1983).

88. In the parlance of the common law," corporeal interests may be acquired by possession, whereas incorporeal interests may be acquired by user. Scholarly justification for these transfers generally falls into two categories: first, adverse possession or prescription Inay bar the owner's remedy and thus leave the disseisor or prescriber with rightful possession or user; second, long user (or, in America, possession) inay raise a presumption of a grant that has subsequently been lost. See William B. Stoebuck, The Fiction of Presumed Grant, 15 KAN. L. REV. 17, 17 (1966).

89. See generally R.D. Cox, Adverse Possession and the Presumption of Title, 11 MEM. ST. U. L. REV. 1 (1980) (discussing the historical development of the presumption and its incorporation into American law, although noting that the presumption is based on a misunderstanding of the English common law); Stoebuck, supra note 88 (discussing the theoretical confusion surrounding prescription and the doctrine of lost grant).

90. BERGER, supra note 87, at 524-25 (citation omitted).

91. Customary usage would justify, for exanple, the right of an entire village to privileges of common pasture in certain parcels of land. Prescription, on the other hand, would award one individual a right to pasture. See Stoebuck, supra note 88 , at 18-19 
To establisl1 a prescriptive property right prior to 1275 , a claimant had to assert that user of the incorporeal property had continued since beyond the meinory of living witnesses or since the Norman Conquest of Britain in 1066..$^{92}$ In 1275, the Statute of Westminster ${ }^{93}$ fixed the date of a writ of riglit ${ }^{94}$ as Ricliard I's accession to the British throne in 1189. Within two liundred years, this date became known as "tlie limit of English legal nemory," 95 and a successful prescriptive claim required proof of user back to $1189 .{ }^{96}$

In 1540, Parliament modified the period of limitations on the writ of right to sixty years, but the courts failed to modify the period for prescriptive claims to inatch this shorter period. ${ }^{97}$ The courts instead cliose to create two presuinptions. First, proof of user as far as living ineinory inferred user all the way back to 1189. This presumption could be defeated by a slowing that user did not exist at soine time since 1189. Second, to avoid the inconvenience of searching for an octogenarian with a particularly fertile meniory, courts created a presuinption that there liad been, at sonie past time, a grant of the incorporeal interest. ${ }^{98}$ The time period necessary to raise this presumptive inference was eventually set at twenty years. ${ }^{99}$

(citing 2 WILIIAM BLACKSTONE, COMMENTARIES *263; EdWARD COKE, FIRST INSTITUTES *113b).

92. See 2 Frederick Pollock \& Frederic W. MaITland, THE history of the ENGLISH LAW 142 (2d ed. 1898) (user pled back to the Conquest); Stoebuck, supra note 88 , at 19 (citing COKE, supra note 91 , at $* 115 \mathrm{~b}$ ) (user "beyond the memory of living witnesses").

93. 3 Edw. 1, ch. 39 .

94. A writ of right was grantable by right, rather than by prerogative, and "lay for one who had the right of property, against another who had the right of possession and the actual occupation." BLACK'S LAW DICTIONARY 1611 (6th ed. 1990). A writ of right secured the return of one's real property. Incorporeal interests were secured through writs "in the nature of a writ of right." Id.

95. See Angus \& Co. v. Dalton, 3 Q.B.D. 85, 104 (1877) (discussing this concept). Thus, any contrary use of the property prior to the accession of Richard I was beyond the limit of English legal memory and, therefore, irrelevant.

96. Id.

97. Stoebuck, supra note 88 , at 20 . Courts had previously applied, by analogy, the period from the writ of right to prescription. Id.

98. Stoebuck places this innovation at the beginning of the seventeenth century. Id.

99. Id. at 20-21. Originally "Iong usage" was sufficient to raise the presumption, but after the 1623 modification of the limitation on ejectment actions to 20 years, the period of user necessary for a presumption of lost grant was set at 20 years. Id. 
During the nineteenth century, the rebuttable presumption of a grant became "irrebuttable" masmuch as courts transforined the evidentiary presumption into a rule of law that vested title in the prescriber. ${ }^{100}$ In 1832, Lord Tenterden's Act $^{101}$ supplemented the common law doctrine of prescription by mandating, inter alia, twenty years user for prescriptive easements and certain water rights before a presumption of grant could arise. The statute also inade these prescriptive interests indefeasible if enjoyed for forty years. ${ }^{102}$

The history of prescription tracks a practice in search of a doctrine; the practice developed before a justification could be found, and Parhament never explicitly dealt with the subject. This failure left courts with the uncomfortable task of refining the doctrine. The English courts developed the fictional lost grant as a doctrinal justification for prescription, but the subsequent legislative actions modifying the requirements of prescription failed to displace the judicially created fiction. William Stoebuck, one of the few scholars who has discussed the problem of lost grant theory, has observed that the presumption of a grant cannot be considered "tlie basis or origin of prescription." 103 American courts, however, have erroneously seen it as the basis not only of prescription but also of adverse possession. ${ }^{104}$

American courts extended the use of lost, or presumptive, grants to the realm of adverse possession and, thus, to corporeal interests. ${ }^{105}$ In so doing, the courts allowed the doctrine of presuned grant, devised as a judicial means of allowing prescription to reseinble the legislative legitimacy of adverse possession, to becoine a justification for adverse possession in American law. Having searched for a justification for the pragmatic doctrine of allowing individual possessors and users to gain title to land and interests, the common law only produced a fiction that continues

100. Id. at 21 (citing William S. Holdsworth, AN Historical INTRODUCTION to THE LAND LAW 283 (1927)). Stoebuck notes that "the presumption could be kept from operating by showing that the facts necessary to raise it had not existed; i.e., that there had been no user for twenty years or that the user had not been uninterrupted, notorious, or hostile to the owner." Id. at 21-22.

101. Prescription Act, 1832, 2 \&.3 Will. 4, ch. 71.

102. Id.

103. Stoebuck, supra note 88 , at $22-23$.

104. Id.

105. See id. at 27-31. 
to confuse both courts and commentators. ${ }^{105}$ The lost grant doctrine has become, in the late twentieth century, an embarrassing illegitimate child of prescriptive law. It is both the misuse of and the disdain for this fiction that postmodern analysis can illuminate.

\section{Postmodern ANALYsis: EMBRACING THE FICTION}

Although twentieth century courts have increasingly viewed the lost grant doctrine as an antiquated remnant of medieval legal thought, ${ }^{107}$ the Utah Supreme Court, in Big Cottonwood Tanner Ditch Co. v. Moyle, ${ }^{108}$ relied on the lost grant doctrine to justify the law of prescription. A postmodern analysis of the ensuing debate in this jurisdiction reveals that there is more at stake than "a fictionalized rationale for the result of the rule."109 Indeed, the strident opposition to the fictional lost grant demonstrates that courts and commentators distrust a legal theory that intimates the fictional nature of property ownership.

Big Cottonwood has been cited as an example of how American courts have misconstrued the doctrine of presumed grant by viewing it as the theoretical basis of prescription. ${ }^{110}$ Despite any conceptual misunderstandings, Big Cottonwood took an anachronistic approach with its expansive use of the lost grant doctrine; it celebrated the fiction as sound doctrine, whereas twentieth century courts and commentators have generally looked on the lost grant doctrine with suspicion or even disdain. ${ }^{111}$ This trend in Ameri-

106. See infra Section III(A).

107. See infra Section III(B).

108. 174 P.2d 148 (Utah 1946).

109. Stoebuck, supra note 88 , at 24 .

110. Id. at $18 \&$ n.3. The fictional lost grant doctriue developed as an ancillary rationale, after prescription was already an accepted means of acquiring a property interest through long-continued user. Id.

111. The lost grant doctrine is generally disfavored, and courts often state that statutes of limitations provide the exclusive foundation for creating property rights through trespass. See, e.g., Dillingham Commercial Co. v. City of Dillingham, 705 P.2d 410, 416 (Alaska 1985); Orange Blossom Hills, Inc. v. Kearsley, 299 So. 2d 75, 76-77 (Fla. Dist. Ct. App. 1974); Garrett v. Gray, 266 A.2d 21, 27 (Md. 1970); Bridle Trail Ass'n v. O'Shanick, 290 S.W.2d 401, 406-06 (Mo. Ct. App. 1956); Plaza v. Flak, 81 A.2d 137, 139 (N.J. 1951); Keebler v. Street, 673 S.W.2d 154, 156-57 (Tenn. Ct. App. 1984); Clark v. Aqua Terra Corp., 329 A.2d 666, 668 (Vt. 1974).

Similar disdam is shown by academics, who dismiss the doctrine in their textbooks. See, e.g., Olin L. Browder, JR. ET AL., Basic Property Law 586 n.4 (4th ed. 1984); Charles Donahue et al., Property 142 n.2 (1983). 
can law is illustrated by a line of Utah cases beginning with the appeal in Big Cottonwood.

\section{A. One Jurisdiction's Interpretive Debate}

Big Cottonwood, as a discussion of the theoretical justification for prescriptive easeinents, provides an excellent context for exainining how modern courts have dealt with the lost grant because almost half a century of subsequent reinterpretation has slowly shaped the disputed context of the lost grant doctrine. The case was actually a rehearing of a prior case on the saine facts, ${ }^{112}$ imvolving an irrigation coinpany's attempt to cement ditches running across the defendants' land. In its first decision, the Utah Supreme Court found that a lower court erred in holding that the plaintiff's proposal to change earthen ditches, which the plaintiff held by prescriptive easeinents, into cement ditches would not, for various reasons, "result in a material increase in the burden on the servient estates."113 The ditches ran through expensive, but arid, residential real estate. The court fonnd that cementing the ditches would kill nearby vegetation and create a greater hazard for children. Because both factors would lower the developmental potential of the land ${ }^{114}$ the court decided that such action would be outside the scope of the prescriptive easement. ${ }^{115}$

On rehearing, a new majority reversed, ${ }^{116}$ changing both the outcome and the nature of the debate by altering the interpretation given to the fictional lost grant. Justice Wolfe, writing for the new majority, noted that cementing the ditches actually eliminated an imcidental benefit, rather than increasing a material burden. ${ }^{117}$ This change im reasoning was based on the reinterpretation of effects flowing from the proposed change in the prescriptive easeinent: vegetation growing on residential property would inevitably die in the absence of seepage from the earthen ditches. ${ }^{118} \mathrm{Al}-$ though, under the English common law, a prescriptive easement could be terminated if the incidental benefits ceased, the court

112. See Big Cottonwood Tanner Ditch Co. v. Moyle, 159 P.2d 596 (Utah 1945), modified on reh'g, 174 P.2d 148 (Utah 1946).

113. Id. at 599.

114. Id. at $596-97$.

115. Id. at 599.

116. See Big Cottonwood, 174 P.2d at 162.

117. Id. at 151-52.

118. Id. at 151 . 
noted that "[t]he needs of the people of this state . . . are materially different from the needs of England." 119

The court cited these differences as the reason that " $[t]$ he common law of Utah presumes that at the time of this grant all parties concerned, knowing of the arid nature of this country, contemplated that at some future time the owner of the water [would modify the structures to prevent waste]."120 The court found it reasonable to conclude that both parties contemplated the arid nature of the land, as well as the potential for ditch improvement. Further, the court utilized this presumed contemplation as a means of ascertaiming the terms of the lost grant. The court refused to allow the servient estate to claim an interest in the seepage water because "the common law of Utah would not read imto the prescriptive use that content."121 Thus, not only was the grant lost, but the court was able to ascertain its contents. Further, the court held that the burdens that a servient owner could enjoin were burdens over and above "those embraced within the framework of the easement itself." ${ }^{222}$ The court thus declined to enjoim the proposed change to the ditches. ${ }^{123}$

Within the confines of this holding, Justice Wolfe made an impassioned argument for the fictional lost grant.

Before I could agree to sweep away the foundation .... I must be convinced that it has become outmoded and useless as the logical basis for ... prescriptive easements. We cannot discard the theory in part and retain it in part. We cannot when it is necessary logically to support some phase or rule of that law, invoke the theory but discard it in favor of some supposedly more realistic theory when our purposes do not seem to require it. I am not yet so convinced. . . The law has texture and continuity. That was the gemius of the common law. The old masters on the bench were able to interpret it as a continuously developing and evolving system with principles inter-related and connected. ... We must be sure that in pulling a master strand in this fabric that we do not destroy the fabric itself. The Legislature nay, if acting constitutionally, do that.... [T] he old judges preserved the logic of the law by what are sometimes called fic-

119. Id. at 152.

120. Id.

121. Id.

122. Id. at 158.

123. Id. at 161 . 
tions but seldom at the cost of substance. This was their method of keeping the law logical and yet making it serve the needs of the people. ${ }^{124}$

This plea for tradition was countered by the concurring opinion of Chief Justice Larson, who argued that the fictional lost grant,

being without basis in fact and without necessity in law, should be utterly disregarded. ... It is merely a legal tower of Babel, which leads to a confusion of tongues. Law should be more realistic-it should stand on its own feet, supported only by its necessity, its reasonableness, and its logic. Whatever may have [been] the seeming necessity in the beginning for the fiction of assuming a grant, it no longer exists. ${ }^{125}$

Chief Justice Larson concluded that "in this day[,] in our law, prescriptive rights are founded upon adverse possession and not upon presumed grants." 126

These two contradictory views form the disputed context within the undisputed law of prescription. One senses an interpretive constraint based on history in Justice Wolfe's opinion and an interpretive constraint based on rationality in Chief Justice Larson's opinion. Subsequent reinterpretations ${ }^{127}$ of this debate, however, would determine the accepted theoretical assumptions behind the law of prescription in Utah.

Although a majority failed to join in the part of Justice Wolfe's opinion dealing with the lost grant doctrine, ${ }^{128}$ subsequent courts did not disturb his reasoning-at least not overtly. A decade later, in Harvey v. Haights Bench Irrigation Co. ${ }^{129}$ the saine Utah court confronted a remarkably sinilar appeal. Noting that "[Big Cottonwood $]$ plagues us ... by" what was said that was not necessary to the decision," the court observed that no opinion in Big Cottonwood garnered more than two votes. ${ }^{130}$ After this criticism, the court produced an analysis that would hold regardless

124. Id. at 153.

125. Id. at 162 (Larson, C.J., concurring).

126. Id. at 163 .

127. See infra notes $129-140$ and accompanying text.

128. Only one justice concurred in both the judgment and the reasoning. Big Cottonwood, 174 P.2d at 162.

129. 318 P.2d 343 (Utah 1957).

130. Id. at $346-47$. 
of whether the justices accepted the lost grant theory or based the right to change the easement's use "in the interest of conservation and public pohicy." 131 The court clearly had misgivings about Big Cottonwood, but it did not repudiate the lost grant doctrine. ${ }^{132}$

A decade later, in Richins $v$. Struhs, ${ }^{133}$ the court spoke, in the context of prescriptive rights, of the "general policy of the law of assuring the peace and good order of society by leaving a longestablished status quo at rest rather than by disturbing it.."134 The court wrote further that

[i]t is appreciated that this lost grant theory is fictional. But the theory upon which the presumption rests is not important. Whatever theory it may be based upon, what is significant is that it has a well justified and salutary purpose which is in conformity with the policy just discussed; and that it is so well established im our law that its validity is no longer open to question. ${ }^{135}$

The opinion analyzed the prescription dispute in light of the law of adverse possession. ${ }^{136}$ Thus, the theoretical assumptions regarding the practice of prescription became part of Utah law through successful acts of persuasion by practitioners and jurists; the court chose not to grapple with the theory behind the practice.

Several years later, tlie saine court stated, im the context of an action to quiet title, "that the policy of encouraging peace and good order and of discouraging trouble and controversy demands [acceptance] as the correct doctrine and that it need not depend upon rationalization as to ideas of estoppel, presumed agreements, lost grants or otlier fictional concepts." ${ }^{137}$ Then, in a 1981 decision, Jensen v. Brown, ${ }^{138}$ the Utah Supreme Court finally found a prescriptive easeinent witlout any inention of the fictional lost grant tlieory. The court relied on traditional adverse possession

131. Id. at 348 .

132. See id. at 349. The court emphasized that Justice Wade's pragmatically oriented opinion in Big Cottonwood "sets out the true basis" for determining the suitability of changes in easement use. Id. The decision, however, proceeded to discuss the facts of the case in the context of analyzing the terms of a lost grant. Id. at 349-50.

133. 412 P.2d 314 (Utah 1966).

134. Id. at 315 .

135. Id.

136. Id. at 316-17. In other words, the inquiry was whether the use was "open, notorious, continuous, and adverse for more than 20 years." Id. at 317.

137. Olsen v. Park Daughters Inv. Co., 511 P.2d 145, 147 (Utah 1973).

138. 639 P.2d 150 (Utah 1981). 
analysis, the interpretation of the traditional terms, "open, notorious, adverse, and continuous [use] for a period of 20 years," to ascertain the existence of a prescriptive easement. ${ }^{139}$ The metaphorical conception of a lost grant was replaced by rehance on a more mechanical approach, ${ }^{140}$ and terms of art within the framework of adverse possession became the accepted discourse surrounding prescription.

These changes in the assumptions behind prescription resulted in a changing interpretive constraimt; in Utah, the rational constraint of Chief Justice Larson prevailed. The acts of persuasion that led to these changes in assumptions, and thus interpretive constraint, must have come from a changing society as well as the preceding opinions. After all, the presumption of a lost grant arose in a time when science postulated a solar system rotating around a flat earth, when divine right determined politics, and when leeches fought rehably against disease. Fictions seent somehow out of context $\mathrm{m}$ a modern society intent on enacting public policies and mechanical rules.

\section{B. Animosity Against Fiction or Prescription?}

Although Big Cottonwood was never overruled, its proposition that the lost grant doctrine was a vital component of prescription gradually fell from favor. These later cases reflect a change in the assumptions about the law. Enlightenment rationality, as reflected by the judicial response to Big Cottonwood, is uncomfortable with the lost grant doctrine. According to the doctrine's detractors, this discomfort has arisen because the doctrine builds on a fiction. Although relatively few acadeınics have devoted attention to the doctrine, one mid-twentieth century commentary stated that "[t]he fiction of a lost grant is quite distasteful to the modern mind,"141 and another found weakness in the doctrine because "it is a palpable and contrived fiction."142

Earker im the century, one writer suggested to American courts that an analogy to the statute of himitations was preferable

139. Id. at 152 .

140. Adverse, for example, was defined as "use ... against the owner as distinguished from under the owner." Id. (quoting Zollinger v. Frank, 175 P.2d 714, 715 (Utah 1946)).

141. 2 AMERICAN LAW OF PROPERTY $\S 8.51$ (A. James Casner ed., 1952).

142. Stoebuck, supra note 88 , at 33 . 
to the doctrine of the lost grant because "[s]uch a rule has the merit not only of attaining fairer results, but also of being based upon fact rather than upon fiction." ${ }^{\text {"143 }}$ Several decades later, J.W. Simonton followed closely on the same theme by arguing that the "adımitted fiction" of lost grant doctrine had "gathered a lot of barnacles, which serve to slow down and clog the admimstration of justice."144 Within the interpretive commumity of American jurists, these and other arguments succeeded im classifymg the doctrine of lost grant as a disputed context ${ }^{145}$ within the undisputed context of prescription. ${ }^{146}$ In other words, everybody agreed that property rights could be acquired through prescription, but opinions varied as to the theory justifying the acquisition. Eventually, the lost grant fell from favor. The interpretive hierarchy was set: prescription by analogy to adverse possession became regarded as a favored conception, a privileged term, whereas prescription by lost grant was disimissed as a mere fiction.

1. Deconstructing the Arguments. Opponents of the lost grant raised two objections. They argued, first, that the conditions necessary to raise the imference of a grant were needlessly coinplex and, second, that the presuinption was not a true presumption because the grant was admittedly a fiction. ${ }^{147}$ These arguments against prescription by analogy to lost grant apply equally well to prescription by analogy to adverse possession. Postmodern analysis can unground the preferred conception of prescription by analogy to adverse possession by mverting this interpretive hierarchy. ${ }^{148}$

The first arguinent against prescription by lost grant attacks the conditions necessary for prescriptive use. The "barnacles" Simonton referred to were terms of art, such as "exclusive" and

143. Note, Doctrine of Lost Grant, 16 HARv. L. REV. 438, 439 (1903).

144. J.W. Simonton, Fictional Lost Grant in Prescription-A Nocuous Archaism, 35 W. VA. L.Q. \& B. 46, 50 (1928). Simonton wrote further that "courts frankly admit they are applying the statute of limitations by analogy. It is therefore time the whole archaic structure was swept away and the simple straight-forward course adopted. The courts of some jurisdictions have done this and no apparent disaster has followed such radicalism." Id.

145. See supra notes $69-70$ and accompanying text.

146. Even today, nobody doubts the ability to gain property interests through prescription, but the lost grant doctrine is still disfavored. See supra note 111 and accompanying text.

147. See infra notes $149-57$ and accompanying text.

148. See supra subsection $\mathrm{I}(\mathrm{B})(1)$. 
"acquiescence," which were required to raise the evidentiary presumption that a grant had been lost. ${ }^{149}$ William Stoebuck has noted, however, that adverse possession began by blending the prescriptive elements into the law to allow possessory acquisition of property; indeed, "the elements [of adverse possession,] 'actual, open, notorious, exclusive, continuous, and hostile[,]' smell suspiciously of Coke's characterization of prescriptive user, 'long, continual, and peaceable." ${ }^{150}$ The terms of art required to raise a presumption of lost grant are very similar to the terms of art required to justify adverse possession. The elements comprising a theory of prescription by analogy to the law of adverse possession therefore bear the same linguistic heritage ${ }^{151}$ as the elements necessary to raise a presumption of lost grant. This common linguistic heritage demands that courts make similar interpretations based on similar terms of art.

Subsequent interpretations have modified the terminology required to acquire property by prescription, but surely prescription's terminology caumot be a justification for abolishing the lost grant, since adverse possession has a sinilar list of conditions. Furthermore, these conditions are equally mystifying to those who must interpret them. These terms have become so frustrating because they are signs (or signifiers) that represent one concept (or siguified) in ordinary usage and another in legal context. ${ }^{152}$ In other words, they have becoine terms of art that courts can use to formulate judicial imterpretations. This judicial reliance on terms of art, however, is the norm in both adverse possession and prescription. ${ }^{153}$ The conceptual theory behind prescription does not change the fundamental acts of imterpretation that a court must perform. Prescription by analogy to adverse possession has just as

149. See Simonton, supra note 144 , at $50-51$.

150. Stoebuck, supra note 88 , at 32 (citing COKE, supra note 91 , at $* 113 \mathrm{~b}$.).

151. One sees the linguistic interdependence, or differance, of these words when it is understood that prescription's terms of art became a justification for adverse possession, and those who dislike the fictional lost grant now seek to infuse these same terms into prescription to give it legitimacy.

152. Words such as "adverse" can mean one thing in common usage and quite another when used as terms of art intended to raise some kind of evidentiary presumption.

153. Simonton noted that "exclusive" often does not mean exclusive, but rather proprietary, and "consent" does not require consent or permission, but means rather that the landowner did not object. See Simonton, supra note 144, at 50-51; see also Note, supra note 143, at 439 (noting the ironic use of "acquiescence" and "interruption" in prescriptive law). 
many barnacles clogging the system and making interpretation difficult as does prescription by analogy to lost grant. The arguments against the lost grant can be said to undo themselves when it is seen that they apply equally well to prescription by analogy as to adverse possession. This reversal shows that there must be some deeper mistrust of the doctrine.

Another argument against the lost grant doctrine criticizes the presumption raised by adverse user. Commentators attack the presumption because it presumes something openly fictional. Simonton argued that the "so-called means of rebutting the presumption do not rebut it, but all of them attack the facts from which the presumption arises and tend to prove the proper facts do not exist." 154 Because the factual basis of the grant could not be attacked, Simonton argued that "the presumption of a lost grant is not a true presumption, because the thing presumed is admittedly a fiction-is admittedly not true in a majority of cases." 155 For Simonton, proof of adverse user "does not justify the inference that there was a grant of the easement which has been lost." ${ }^{\text {156 }} \mathrm{He}$ objected to the presumption because evidence that a grant was never inade caumot be introduced; evidence about the character of the user is the only evidence that is admissible. Inability to consider factual evidence concerning the grant, he argued, undermines the presumption because it was a presumption of a grant that was completely fictional. ${ }^{157}$

The saine argument, however, may be used against prescription by analogy to adverse possession. If, as the lost grant doctrine's detractors argue, proof of adverse user does not justify the inference of a grant, then one might rightfully question what type of inference is justified. It appears that the detractors believe that proof of user justifies a decision based on a set of adverse possession's terms, even if these terms were actually derived from and very similar to the terminology used to infer the existence of a grant and thereby satisfy the requirements of prescription. The argument against the fiction denigrates the presumption of a grant,

154. Simonton, supra note 144 , at 50 .

155. Id. at 48 .

156. Id.

157. British conrts have encountered this same problem in applying their own common law. Evidence to rebut the user, but not evidence to rebut the grant, is admissible. Alan Dowling, Note, Lost Grants and Registered Deeds, 43 N. IR. LEGAL Q. 53, 53-54 (1992). 
but Simonton's argument necessarily relies on a presumption that fulfilling the requirements of adverse possession justifies the transfer of property. With or witlout the presumption of lost grant, there is no difference in outcome. The dissatisfaction, therefore, appears to be focused on the artificial nature of the fictional grant, rather than on the logical weakness of the evidentiary rules.

2. Interpreting the Constraint. In addition to showing low these arguments against the lost grant doctrine deconstruct, postmodernism also casts light on the interpretational process and reveals the equally fictitious nature of the rational approaches advocated in place of the lost grant doctrine. In liberating the text froin the autlior and questioning the simple paradigm of legal interpretation, ${ }^{158}$ postinodernism can displace the idea that correct interpretations follow the author's intent and incorrect interpretations miss the autlor's intent. Thus, although there was no intent to grant the property right, the lost grant theory can be accorded equal footing witlı other theories regardless of the parties' intent-it is a conceptual model that serves as a inetaplior, an arbiter of competing interests. There is always a divergence between intent and the actual signs and inetapliors of a text. A conceptual model serves a relevant purpose and is just as valid, even if it is not as easily perceptible as a meclianical test sucl as prescription by analogy to adverse possession.

That mecliamical test, however, becaine the accepted means of understanding prescription because the interpretive coinmunity of American lawyers, jurists, and academicians finally accepted a "rational" interpretive constraint that disfavored the lost grant theory. ${ }^{159}$ The "ineaning" of prescription, determined by the community's innate structure of beliefs, ${ }^{160}$ gradually clianged. This analysis of interpretation not only explains the process of historical developinent but also implies the possibility of future cliange. Interpretive constraints of the future need not perpetuate the philosophical bias of Enlightenment rationality.

Interpretive constraint, although itself a niediating force, may yet transform under the influence of postmodernisin. If postmodernisn influences the structure of beliefs innate to Auneri-

158. See supra subsection $\mathrm{I}(\mathrm{B})(2)$.

159. See supra notes $129-40$ and accompanying text.

160. See supra note 66 and accompanying text. 
can legal thought, hostihty to metaphor and symbol will dissipate. In the subsequent reinterpretations of Big Cottonwood, modernism pushed aside the lost grant doctrine and replaced it with rules that appear more rational. Postmodern analysis, however, can expose the equally fictitious nature of modernism's rational rules.

3. Drawing Conclusions. The deconstruction of modern assumptions about prescription brings us back, in a sense, to where we began. The interpretive hierarchy has been reversed. Arguments against prescription by analogy to lost grant have been shown to apply equally well to prescription by analogy to adverse possession. Once the preferred conception has been ungrounded, there reinams to be seen what insights this ungrounding might offer. The objections to prescription by lost grant appear to be focused on the fictional nature of the doctrine; this fiction contrasts with a view of property law characterized by mechanical rules. To "rational" minds, mechanical rules imply legitimacy. Ownership of property or property rights appears more legitimate when justified by mechanical approaches.

Advocating just such an approach, Simonton sought to show that prescription by lost grant had become, in effect, just like adverse possession. He wrote that "[t]he reluctance of the Enghish courts to admit they were actually making law, seemingly caused them to adopt the fiction and thus pretend they were merely applying law already existing."161 The lost grant doctrine, however, probably found its origin in efforts to justify prescription, rather than in efforts to obscure reasoming. Judges created the common law; it seems unlikely that they would invent the lost grant doctrine out of a desire to deny their hand in legal creation. Because theories of prescription seem to be efforts at cloaking the property transfer in legitimacy, a discomfort with prescription in general is a more likely antecedent of the fictional lost grant.

One sees this discomfort in the history of prescription. The fictional lost grant developed after prescription was already an established practice. ${ }^{162}$ Both courts and legislatures danced around prescription without ever coming to conclusive answers

161. Simonton, supra note 144 , at 50 .

162. See supra Section II(B). Additionally, Parliament's 1832 act, called Lord Tenterden's Act, 2 \& 3 Will. 4, ch. 71, failed to do anything more than supplement this common law practice. See supra text accompanying note 101. 
about its doctrinal basis. ${ }^{163}$ Beneath the surface, the same discomfort motivates detractors of the fiction in our own time.

This discomfort arises because awarding property rights is, in and of itself, a construct-a fiction. Dirt, rocks, and ditches only become "property" when the law symbohcally sanctions "ownership." Without this legal sanction, only brute force would ensure property ownership. The judges and legislators of prior times needed a rationale for their pragmatic practice of awarding interests in land to those who used it for a significant amount of time. The lost grant theory fit well as a justification for the transaction. The distrust subsequently aimed at the fictional lost grant seems to posit reality as an appropriate counterpart to fiction. In this artificial hierarchy, reahty is a privileged conception and the fictional construct is disfavored. This opposition to fiction may be explained by Derrida's metaphysics of presence because his philosophical conception discerns philosophical bias in our attempts to privilege the ideas that seem inost immediately perceptible. ${ }^{164}$

Modernism does not view the fictional construct as the most obvious approach, but prescription, sanctioning property acquisition through trespass, requires that courts indulge in fiction. In this sense, property rights are not objectively real-they are legal fictions placed over possession and use for the sake of ensuring domestic tranquility. Fiction and reality, however, both bear traces of each other because each word is implicit in the other word's definition. ${ }^{165}$ When we hold reality before our mind, we know that it is not fiction, and when we hold fiction before our mind, we know that it is not reality. The differance, ${ }^{166}$ or mutual dependence, of these terms is apparent. As has been argued, however, legal reahty in the sense of property rights is a fictional construct. Postmodern legal theory allows a fiction to be accorded just as much legitimacy as legal "reahty."

Postmodern approaches to law readily acknowledge its fictional nature, but modern minds want a mechamical law that, through objective reahty, smoothly accomplishes its purpose. To thein, the lost grant theory appears to be excess theoretical baggage that detracts froin the mechanics. They do not want to think that there

163. See supra text accompanying notes 103 .

164. See supra note 40 and accompanying text.

165. See supra note 43 and accompanying text.

166. See supra note 44 and accompanying text. 
might be a certain level of incongruence between their language and their intention or between a law's justification and its application. The reahty is that there was no grant, but one also might argue that another reality is tliat our conception of property ownership is a construct just like the lost grant. Allowing adverse user (itself a term of art) to become a property right is a pragmatic necessity in our society; but to dismiss a meclianisnı for acconlphishing this result as a fiction strikes an ironic chord. ${ }^{167}$.

This irony should not be lost on courts, academics, or practitioners. Perhaps openly acknowledging the presence of fiction in legal endeavor would facilitate more open discourse and lead to greater equity. Those who deny fictions by advocating mechanical approaches should reevaluate the reasons behind their distaste for metaphorical conceptions such as the lost grant. Understanding the utility of a perspective enriched by the lost grant allows legal practitioners to look deeper into the process in which they are engaged.

The law is now centuries from hivery of seisin, ${ }^{168}$ but that practice, which symbolized possession, may be an appropriate comparison to the lost grant. Modernism sees symbohic rites as archaic and fictional acquisitions as superfluous, but postmodermisin can posit these conceptual models as equally valid alternatives. Prescription imvolves analysis of terms of art and can take on the aura of a mechanical process. Removing the fiction as a conceptual model pushes the reasoning for the transfer into a purely linguistic realin and therefore makes the property transfer appear more rational and legitimate. The fiction, however, is more honest. Nobody would advocate a return to medieval ritual, but perhaps those who practiced the rituals could better understand that ownership is a symbolic fiction that we place over possession. Although the modern mind is more comfortable with ownership, possession and ownership are two signifiers that represent the

167. Irony may be the defining quality of the lost grant doctrine. Either attacking or supporting the doctrine appears ironic when the arguments are undermined. One writer has observed that, in modern British common law, the effect of mistake on the element of acquiescence remains miportant, although the grant is presumed. See Hudson, supra note 75 , at $356-60$.

168. Prior to 1536 , a freehold estate could be transferred only through a ceremonial ritual known as a feoffment with livery of seisin. This rite required the grantor and grantee to enter the land, with witnesses, to exchange a twig, a clod of dirt, or a key as a symbolic transfer of the property. See DUKEMINIER \& KRIER, supra note 74, at 394. 
same signified. Because it reveals the unstable nature of language and signification, postmodern analysis shows that ownership and possession are metaphors inside a complex, symbolic structure of fictional concepts.

\section{CONCLUSION}

Even if we deny them, fictions nonetheless surround us. An objective view of the world based on scientific rationalism strives to eliminate ambiguity, but only at the price of creatimg more subtle fictions. Ownership is one such fiction, as is the acquisition of property rights through prescription. Although inodernism has eliminated the lost grant doctrine froin the conceptual framework of prescription, postmodernisin reveals the equally fictional nature of the remaining structures. The fictional lost grant accoinphished the same purpose as reasoning by analogy to the elements of adverse possession, ${ }^{169}$ but even according to the standards of Enligltenment rationality, it had the advantage of openly admitting its contrivance. The mechanical rules of adverse possession give the appearance of rationality, but they are structures for interpretation just as much as any elements of prescription; they appear cleaner only because they purport to build on a solid foundation instead of a fiction.

Postmodernism allows the theory of prescription by analogy to lost grant to be accorded just as much vahidity as its alternative. ${ }^{170}$ The lost grant doctriue inakes overt that which modernism strives to subvert; despite rational, scientific thought and organized legal structures, we are surrounded by fiction. Viewed through a postmodern lens, our objective construct of ownership is undermined by subjective msights into its fictional nature. Shakespeare evoked this clash between objective and subjective perspectives witl his proposition that mere thought could make Denmark a prison. He surely would be disinayed, however, by a modern world that cannot admit its fiction. This is a prison of the mind.

169. See Stoebuck, supra note 88 , at 31 .

170. One legal scholar has argued that the lost grant doctrine should be accepted, even in modern practice, because it fills four conceptual holes: claims to government lands, claims against future interests, claims founded on interrupted possession or use, and claims against concurrent owners. See Jerome J. Curtis, Jr., Reviving the Lost Grant, 23 Real Prop. Prob. \& Tr. J. 535, 548-58 (1988). 